\title{
Vaistas Relvar Ellipta, palyginus su ịprastu gydymu, reikšmingai pagerino Salfordo plaučių tyrime dalyvavusių pacientų astmos kontrolę
}

\author{
RELVAR ELLIPTA SIGNIFICANTLY IMPROVED ASTHMA CONTROL IN \\ SALFORD LUNG STUDY PATIENTS COMPARED WITH THEIR USUAL CARE
}

KĘSTUTIS MALAKAUSKAS

LSMU MA Pulmonologijos klinika

\begin{abstract}
Santrauka. Salfordo plaučiu tyrimas yra daugelyje bendrosios praktikos centru atvirai atliktas atsitiktiniu imčiu kontroliuojamasis tyrimas. Tyrimo metu nustatyta, kad flutikazono furoato ir vilanterolio (Relvar Ellipta) deriniu 52 savaites gydytiems pacientams, sergantiems simptomine astma, buvo geresné astmos kontrole be dažnesniu sunkiu nepageidaujamu reiškiniu, palyginus su pacientais, tęsusiais ịprastą gydymą.
\end{abstract}

Reikšminiai žodžiai: astma, flutikazono furoatas, vilanterolis, Salfordo plaučiu tyrimas.

Summary. Salford Lung Study is an open-label, randomised, controlled, two-arm effectiveness trial at general practice clinics. In patients with symptomatic asthma and on maintenance inhaler therapy, initiation of a oncedaily treatment regimen of combined fluticasone furoate and vilanterol (Relvar Ellipta) for 52 weeks improved asthma control without increasing the risk of serious adverse events when compared with optimised usual care.

Key words: asthma, fluticasone furoate, vilanterol, Salford Lung Study.

Astma yra lètinè plaučių liga. Sergant šia liga pasireiškia kvèpavimo takų uždegimas ir obstrukcija. Astma serga 358 milijonai žmonių visame pasaulyje. Astmos priežastys nèra pakankamai ištirtos, bet tikètina, kad liga pasireiškia dèl genetinių ir aplinkos veiksnių sąveikos.

Astmos kontrolè vis dar išlieka tikras iššūkis pacientams ir sveikatos priežiūros bendruomenei. Bloga astmos kontrolè gali turèti didelę itaką astma sergančių pacientų gyvenimo kokybei. Sunku tirti skirtingu gydymo būdų ịtaką astmos kontrolei ịprastais dvigubai koduotais atsitiktinių imčių kontroliuojamaisiais tyrimais, nes tyrimo dizainas ir intensyvi stebèsena gali veikti pacientu elgesį. Salfordo plaučių tyrimas (angl. Salford Lung Study) sumodeliuotas siekiant išsiaiškinti, kaip vaistai astmai gydyti veikia kasdienejje klinikinejje praktikoje. Pirminè vertinamoji šio tyrimo baigtis parode, kad, pacientus pradejjus gydyti Relvar Ellipta, astmos kontrolès pagerèjimo galimybè padidejo dukart, palyginus su pacientais, kurie ir toliau buvo gydyti ịprastai šio tyrimo metu kasdieneje klinikinèje praktikoje.

Salfordo plaučių tyrime dalyvavo 4233 astma sergantys pacientai, gydyti jų bendrosios praktikos gydytojų kasdienejje klinikinëje praktikoje. Šis atviras atsitiktinių imčių tyrimas parodè, kad reikšmingai didesnè dalis astma sergančiu pacientų, kurie pradejo gydytis

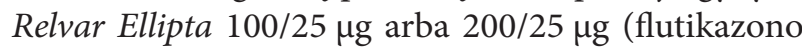
furoatu, vilanteroliu arba FF/VI), pasieke geresnę astmos kontrolę, palyginus su pacientais, kurie tęsè ipprastą gydymą. Taigi, ịprastą gydymą sudare ịkvepiamieji gliukokortikoidai (IGK), vartoti vieni arba deriniuose su ilgo veikimo $\beta$-adrenoreceptorių agonistu (IVBA).

Remiantis pirmine veiksmingumo duomenų analize, reikšmingai daugiau pacientų sergančių nekontroliuojama astma, pradejusių gydymą FF/VI, pasiekè geresnę astmos kontrolę (71 proc.) 24-ąją savaitę, remiantis astmos kontrolès testo (AKT) duomenimis, palyginus su pacientais, kurie tęsè iprastą gydymą ( 56 proc.) (galimybių santykis $-2,00,95$ proc. pasikliautinasis intervalas $1,70-2,34 ; \mathrm{p}<0,001)$. Pagerèjimu buvo laikomas astmos kontrolès testo (AKT) bendrasis balas $\geq 20$ arba jo padidejjimas $\geq 3$, palyginus su pradiniu. Statistiškai reikšmingi rodmenys stebeti ir 12-ąją, 40-ąją bei 52-ają savaitę.

Remiantis ị tyrimą įtrauktų numatytų gydyti pacientu (angl. the intent-to-treat, ITT) populiacijos duomenimis, sunkių nepageidaujamų reakcijų dažnis abiejose grupese buvo toks pat (FF/VI grupèje - 13 proc., iprasto gydymo grupeje - 13 proc.). Pneumonija buvo labai svarbi saugumo vertinamoji baigtis ir, reikalaujant Europos vaistų agentūrai (angl. European medi- 


\section{Farmakoterapija}

cines agency, EMA), stebima ir užregistravus vaistinị preparatą. Naujas aspektas tyrimo dizaine buvo tai, kad buvo leidžiama keisti paciento gydymą tyrimo metu. Todèl paciento būklè pneumonijos požiūriu buvo vertinta du kartus: pirmą kartą - atsitiktinai suskirsčius ị grupes, antrą - gydymo metu, tada, kai pacientas patyrè šią nepageidaujamą reakciją. Pneumonija registruota 39 pacientams atsitiktinių imčiu grupèse: FF/VI grupeje - 23 pacientams (1 proc.), iprasto gydymo grupeje -16 ( $<1$ proc.). Šie pacientai patyrè 42 pneumonijos atvejus, juos apibendrinus, atsižvelgiant i pacientams tuo metu taikytą konkretu gydymą, 21 atveju pneumonija pasireiške vartojant FF/ VI, 21 atveju - iprasto gydymo metu.

\section{TYRIMO PLANAS}

Salfordo plaučių tyrimas yra daugelyje centrų atvirai atliktas III fazès atsitiktinių imčių kontroliuojamasis tyrimas. Šio tyrimo tikslas buvo palyginti realaus veiksmingumo ir saugumo duomenis pradejus gydyti FF/VI su iprastu palaikomuoju astmos gydymu per 52 savaičių laikotarpi. Visi astma sergantys pacientai, atitinkantys ịtraukimo ị tyrimą kriterijus, 74 pirminès priežiūros centruose Salforde ir Pietų Mančesteryje bei jų apylinkèse (Jungtinèje Karalystėje) buvo atrinkti pagal centrų duomenų bazes. Dalyvauti tyrime juos kvietė gydantys šeimos gydytojai. Šio tyrimo pirminè vertinamoji baigtis buvo nustatoma 24-ąją savaitę atliekant pirminę gydymo veiksmingumo analizę populiacijoje.

Iš viso 4233 astma sergantiems pacientams, kurie vartojo IGK su (be) IVBA, atsitiktinai buvo skirta arba vartoti FF/VI, arba tęsti jau taikomą palaikomąji astmos gydymą (iprasto gydymo grupè).

Iprasto gydymo grupès vaistus skyrè paciento bendrosios praktikos gydytojas, tai buvo arba IGK, arba IGK kartu su IVBA. Pradedant vartoti tiriamą vaistinị preparatą, 36 proc. ịprastos priežiūros grupès pacientų buvo gydyti vien IKS, 64 proc. - IGK/IVBA deriniu.

Salfordo plaučių tyrimas turẻjo minimalų neįtraukimo ị tyrimą kriterijų skaičių ir didelę pacientų demografinę ịvairovę. Pradedant tyrimą, pacientų amžiaus vidurkis buvo 49,8 metų (jauniausiam pacientui - 18 metų), tiriamieji buvo suskirstyti pagal lytị (vyriškosios lyties - 41 proc., moteriškosios - 59 proc.). Ittrauktiems i tyrimą pacientams bendrosios praktikos gydytoju diagnozuota astma turejo būti svarbiausia jų kvėpavimo organų liga ir palaikomajam gydymui jie turejo būti vartoję IGK su IVBA arba be IVBA ne trumpiau kaip keturias savaites iki antro [2] vizito. Pradedant tyrimą 72 proc. pacientų astma buvo nekontroliuojama jiems nustatytas bendrasis AKT balas - nuo 5 iki 19.

Pacientai buvo stebèti 52 savaites kasdienès klinikinès praktikos sąlygomis, tyrimo duomenims rinkti naudojant elektroninių medicininių dokumentų įra- šus, siejančius pirminès sveikatos priežiūros, antrinės sveikatos priežiūros ir vaistinių duomenis. Tyrimo metu gydytojai bet kuriuo laiku galejo keisti gydymą taip, kaip tai daroma iprastoje klinikinejje praktikoje. Vienintelè išimtis - ịprasto gydymo pakeitimas į FF/VI.

12-ąją, 24-ąją ir 40-ąją savaitemis pacientai buvo apklausiami telefonu, siekiant sužinoti, ar jie patyrè sunkių nepageidaujamų reakcijų arba nesunkių nepageidaujamų reakcijų i vaistini preparatą. Telefoninio pokalbio metu pacientų buvo prašoma atlikti AKT. 12-ąji mènesi pacientai apsilankè pas gydytoją. Be to, 24-ąją ir 40-ąją savaitèmis telefoninio pokalbio metu pacientai buvo apklausiami naudojant Standartini astma sergančių pacientų gyvenimo kokybès klausimyną (angl. the Standardised Asthma Quality of Life Questionnaire, AQLQ).

Tyrimo komanda, stebėdama elektroninius sveikatos įrašus, galèjo stebèti visus gydymo ligoninèje, pacientų apsilankymo ambulatorineje įstaigoje arba skubiosios pagalbos skyriuje atvejus, taip pat pirminès sveikatos priežiūros duomenis (įskaitant visus kreipimusis $\mathfrak{i}$ sveikatos priežiūros ịstaigą, vizitus po darbo valandų ir antibiotikų arba geriamųjų gliukokortikoidų skyrimo atvejus).

Numatytų gydyti pacientų populiacija buvo apibrèžiama kaip visi pacientai, kurie suvartojo bent vieną atsitiktinai skirtą tiriamo vaistinio preparato dozę (t. y. FF/VI arba iprasto palaikomojo gydymo vaistinị preparatą pagal ịprastą astmos gydymą). Pirminès veiksmingumo analizès populiacija buvo apibrèžiama kaip visi numatyti gydyti pacientai, kurių pradinis bendrasis AKT balas buvo $<20$ (per randomizacijos vizitą).

Galimybių santykis, nurodytas rezultatuose, apskaičiuotas kaip galimybès pasiekti geresnę astmos kontrolę pacientams, pradejusiems gydymą Relvar Ellipta, santykis su galimybe pasiekti geresnę astmos kontrolę tęsiant ịprastą gydymą. Šis rodmuo yra patikslintas, atsižvelgiant ị bet kurios svarbios charakteristikos tarp gydymo grupių neatitikimą.

\section{ASTMOS KONTROLĖS TESTAS}

AKT yra visuotinai pripažinta priemonè, naudojama visame pasaulyje Astmos gydymo gairèse vertinant astmos kontrolę. Tai yra savarankiškai atsakomi penki klausimai, pagal kuriuos galima įvertinti astmos kontrolę per praejusias keturias savaites pagal penkių kategorijų skalę (nuo 1 iki 5 balų). Atsakius ị visus penkis klausimus, astma sergantis pacientas gali suskaičiuoti nuo 5 iki 25 balų; didesnis balas rodo geresnę kontrolę.

Bendrasis AKT balas nuo 5 iki 19 rodo, kad paciento būklè yra blogai kontroliuojama arba visai nekontroliuojama. Bendrasis balas nuo 20 iki 25 rodo, kad paciento astma greičiausiai yra gerai kontroliuojama. Bendrasis balas apskaičiuojamas kaip balų, suskaičiuotų atsakius ị penkis klausimus, suma, nepraleidžiant nè 


\section{Farmakoterapija}

vieno balo. Jeigu buvo praleistas nors vienas atskiras balas, bendrasis balas vertinamas kaip nesamas. Pokytis trimis balais yra kliniškai reikšmingas pacientui.

\section{APIE TYRIMA}

Salfordo plaučių tyrimas skirtas padèti sveikatos priežiūros specialistams ir sprendimus priimantiems asmenims aktyviau įvertinti galimą gydymo FF/VI reikšmę pateikiant kasdienès klinikinès praktikos sąlygomis surinktus duomenis. Jie rodo, kaip sveikatos priežiūros specialistai ir pacientai gali vartoti vaistinị preparatą kasdieniame gyvenime. Jie papildo turimus duomenis, gautus dvigubai koduotų vaistinio preparato klinikinių atsitiktinių imčių tyrimų metu, kurie, nors ir yra būtini norint įvertinti vaistinio preparato saugumą ir veiksmingumą, atliekami griežtai kontroliuojamomis sąlygomis ir ị juos ịtraukiama griežčiau atrinktų pacientų populiacija nei galima tikètis kasdienejje klinikinèje praktikoje.

Tyrimas tapo įmanomas dèl unikalaus GSK, Šiaurès Vakarų sveikatos priežiūros elektroninès sistemos (angl. the North West e-Health, NWEH), Mančesterio universiteto, Salfordo Karališkojo Nacionalinès sveikatos apsaugos draudimo (angl. the Royal NHS Foundation Trust), Pietų Mančesterio universitetinès ligoninès (angl. the University Hospital of South Manchester, UHSM), Salfordo NHS ir Salfordo bendrosios praktikos gydytojų ir vaistininkų bendruomenès bendradarbiavimo.

\section{APIE RELVAR ELLIPTA (FLUTIKAZONO FUROATAS IR VILANTEROLIS)}

Relvar Ellipta yra vieną kartą per parą vartojamas vaistų derinys, kurio sudetyje yra IGK flutikazono furoato ir IVBA vilanterolio viename Ellipta inhaliatoriuje.

Europoje Relvar Ellipta skirtas reguliariai gydyti astma sergantiems 12 metų ir vyresniems pacientams, kuriuos tinka gydyti vaistų deriniu (IGK ir IVBA): pacientams, kurių būklė nepakankamai kontroliuojama IGK, kartu, prireikus, vartojant ikvepiamuosius trumpo veikimo $\beta_{2}$-adrenoreceptorių agonistus.

\section{SVARBI RELVAR ELLIPTA SAUGUMO INFORMACIJA EUROPOJE}

FF/VI negalima vartoti pacientams, kuriems pasireiškia padidejęs jautrumas flutikazono furoatui, vilanteroliui arba bet kuriai pagalbinei vaistinio preparato medžiagai.

FF/VI negalima vartoti ūminiams astmos simptomams gydyti arba paūmèjus lètinei obstrukcinei plaučių ligai (LOPL). Jeigu reikia, šiais atvejais reikia vartoti greito veikimo bronchų plečiamuosius vaistinius preparatus. Padidejęs greito veikimo bronchų plečiamųjų vaistinių preparatų suvartojimas rodo kontrolès pablogejjimą ir gydytojas turi ištirti pacientą pakartotinai.

Pacientams negalima nutraukti astmos arba LOPL gydymo FF/VI, jei jų neapžiūrèjo gydytojas, nes, nutraukus gydymą, simptomai gali pasikaroti.

Gydant FF/VI gali pasireikšti su astma susijusių nepageidaujamų reakcijų ir paūmèjimų. Pacientų reikia prašyti, kad tęstų gydymą, bet kreiptųsi medicininès pagalbos, jeigu astmos simptomai išlieka nekontroliuojami arba pasunkèja, pradejjus gydymą FF/VI.

Gali ištikti paradoksalus bronchų spazmas - tai pasireiškia švokštimu iš karto suvartojus dozę. Tokiu atveju nedelsiant reikia vartoti greito veikimo bronchụ plečiamųjų vaistinių preparatų. Reikia iškart nustoti vartoti FF/VI, įvertinti paciento būklę ir, prireikus, skirti kitoki gydymą.

Vartojant simpatomimetinio poveikio vaistinius preparatus, ịskaitant FF/VI, gali pasireikšti poveikis širdžiai ir kraujagyslemms, pvz., širdies aritmijos (pvz., supraventrikulinè tachikardija ir ekstrasistolès). Todèl FF/VI reikia atsargiai vartoti pacientams, sergantiems sunkia širdies ir kraujagyslių sistemos liga.

Pacientams, kuriems pasireiškia vidutinio sunkumo arba sunkus kepenų funkcijos sutrikimas, reikia vartoti 92/22 $\mu$ g dozę ir juos reikia stebèti, nes gali pasireikšti su gliukokortikoidais susijusių sisteminių nepageidaujamų reakcijų. 184/22 $\mu$ g FF/VI dozè neskiriama vartoti LOPL sergantiems pacientams. Papildomo naudingo poveikio, vartojant $184 / 22 \mu \mathrm{g}$ dozę, palyginus su 92/22 $\mu$ g doze, nepastebèta, bet gali padideti pneumonijos ir su gliukokortikoidais susijusių sisteminių nepageidaujamų reakcijų rizika.

Pastebėtas pneumonijų padažnėjimas LOPL sergantiems pacientams, vartojantiems FF/VI. Be to, pacientus dèl pneumonijų dažniau teko gydyti ligoninèje. Kai kurie tokie pneumonijų atvejai buvo mirtini.

Astma sergantiems pacientams pneumonija pasireiškè vartojant didelę dozę. Anksčiau atlikto astmos gydymo FF/VI tyrimo duomenimis, pneumonijos dažnis astma sergančių pacientų, vartojusių 184/22 $\mu \mathrm{g}$ FF/VI dozę, grupejje skaičiumi buvo didesnis, palyginus su tais pacientais, kurie vartojo 92/22 $\mu \mathrm{g}$ FF/VI dozę arba placebą.

Gauta pranešimų apie gliukozès koncentracijų cukriniu diabetu sergančių pacientų kraujyje padidejjimą ir i tai reikia atsižvelgti skiriant vaistinị preparatą pacientams, sergantiems cukriniu diabetu.

Vartojant bet kuriuos IGK, ypač dideles jų dozes ilgą laikotarpi, gali pasireikšti sisteminis poveikis. Tokio poveikio atsiradimo tikimybė yra mažesnè nei vartojant geriamuosius gliukokortikoidus. Galimas sisteminis poveikis yra Kušingo sindromas, kušingoidinės savybės, antinksčių funkcijos slopinimas, kaulų mineralinio tankio sumažejimas, vaikų ir paauglių augimo sulètejjimas, katarakta ir glaukoma, rečiau: ịvairūs 


\section{Farmakoterapija}

psichikos arba elgesio sutrikimai, įskaitant pernelyg didelị psichomotorinị aktyvumą, miego sutrikimus, nerimą, depresiją arba agresyvumą (ypač vaikams).

FF/VI reikia atsargiai vartoti tuberkulioze sergantiems pacientams arba pacientams, sergantiems lètinėmis arba negydytomis infekcinėmis ligomis. Nepageidaujamų reakcijų, susijusių su FF/VI vartojimu, dažniai buvo apskaičiuoti, remiantis didelių astmos ir LOPL klinikinių tyrimų duomenimis.

Labai dažnos nepageidaujamos reakcijos (pasireiškè dažniau kaip 1 iš 10 pacientų), vartojant FF/ VI, buvo galvos skausmas ir nazofaringitas. Dažnos nepageidaujamos reakcijos (pasireiškè dažniau kaip 1 iš 100 , bet rečiau kaip 1 iš 10 pacientų) buvo pneumonija, viršutinių kvèpavimo takų infekcinè liga, bronchitas, gripas, burnos ir gerklès kandidamikozè, burnos ir gerklès skausmas, sinusitas, faringitas, rinitas, kosulys, disfonija, pilvo skausmas, artralgija, nugaros skausmas, lūžiai, karščiavimas ir raumenų spazmai. Ekstrasistolès užfiksuotos kaip nedažnos nepageidaujamos reakcijos (pasireiškè dažniau kaip 1 iš 1000 , bet rečiau kaip 1 iš 100 pacientų). Retos nepageidaujamos reakcijos (pasireiškè dažniau kaip
1 iš 10000 , bet rečiau kaip 1 iš 1000 pacientų) buvo padidejusio jautrumo reakcijos (ịskaitant anafilaksiją, angioneurozinę edemą, išbèrimą ir dilgèlinę), nerimas, drebulys, palpitacijos, tachikardija ir paradoksalusis bronchų spazmas. Saugumo duomenys astma sergantiems pacientams ir LOPL sergantiems pacientams buvo panašūs, išskyrus duomenis apie pneumoniją ir lūžius. Klinikinių tyrimų metu pneumonija ir lūžiai LOPL sergantiems pacientams buvo diagnozuoti dažniau.

Straipsnio publikaciją remia sveikatos priežiūros bendrove "GlaxoSmithKline Lietuva“

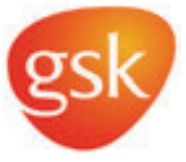

LT/FFT/0028/17, paruošta 201709

\section{LITERATŪRA}

1. Woodcock A, Vestbo J, Bakerly ND, New J, Gibson JM, McCorkindale $\mathrm{S}$ et al. Effectiveness of fluticasone furoate plus vilanterol on asthma control in clinical practice: an open-label, parallel group, randomised controlled trial. Lancet 2017 Sep 10: DOI: http://dx.doi.org/10.1016/S0140-6736(17)32397-8. 